University of Nebraska - Lincoln

DigitalCommons@University of Nebraska - Lincoln

Faculty Publications: Department of Teaching, Department of Teaching, Learning and Teacher Learning and Teacher Education

2009

Teacher Investment in Learner Identity

Jenelle Reeves

University of Nebraska-Lincoln, jreeves2@unl.edu

Follow this and additional works at: https://digitalcommons.unl.edu/teachlearnfacpub

Part of the Teacher Education and Professional Development Commons

Reeves, Jenelle, "Teacher Investment in Learner Identity" (2009). Faculty Publications: Department of Teaching, Learning and Teacher Education. 106.

https://digitalcommons.unl.edu/teachlearnfacpub/106

This Article is brought to you for free and open access by the Department of Teaching, Learning and Teacher Education at DigitalCommons@University of Nebraska - Lincoln. It has been accepted for inclusion in Faculty Publications: Department of Teaching, Learning and Teacher Education by an authorized administrator of DigitalCommons@University of Nebraska - Lincoln. 


\title{
Teacher Investment in Learner Identity
}

\author{
Jenelle Reeves \\ University of Nebraska-Lincoln \\ Lincoln, Nebraska, USA \\ jreeves2@unl.edu
}

\begin{abstract}
From a sociocultural perspective, teacher identity is constructed in relation to others, including other teachers and students. Drawing on positioning theory and the concept of investment, this study analyzed the case of a secondary English teacher who negotiated his teacher identity in relation to English language learners (ELLs). Findings indicated that the teacher made an investment in ELLs' identity by positioning them as like any other student. The desired return on the teacher's investment was a strengthened self-positioning as a natural and highly competent teacher. The implications of teacher investment in learner identity for teacher practice, learner identity construction, and teacher education are discussed.
\end{abstract}

Keywords: teacher identity, student identity, sociocultural theory, teacher education, English language learners, positioning theory, investment

Recent educational research has provided rich demonstration of identity as a relational, socially negotiated process (Goldstein, 2003; Harklau, 2000; Johnson, 2006; Lasky, 2005; Marsh, 2002; Morgan, 2004; Soreide, 2006; Toohey, 2000; Watson, 2006). Such studies feature teachers and students engaged in identity negotiations where individuals claim, assign, and reject identities in relation to others, including in relation to other teachers and students. The relational nature of identity means that individuals are not the sole constructors of their identity, that identity is no longer viewed as an entirely internal process. Rather, identity is coconstructed with interested others. To date, identity research in educational settings has largely focused on the identity processes of students (e.g. Goldstein, 2003; Harklau, 2000; Olsen, 1997; Valdes, 2001), and within that scholarship, teachers' roles in student identity construction are suggested. For example, teachers have been observed to assign unwanted identities to students (e.g. the "worst" students in Harklau, 2000), identities students adapt, adopt, or reject. Yet, despite promising scholarship interrogating student identity in relation to teachers, little is known about teacher identity in relation to students. This study examined the process by which a teacher invested in English language learners' (ELLs) identity as a means to negotiate his own teacher identity.

ELLs are enrolling in increasing numbers in public schools throughout the United States as well as Canada, the United Kingdom, Australia, and New Zealand. Further, ELLs are entering schools in new lo- cales, such as the interior United States, that had become unaccustomed to linguistic diversity during the mid-and late 20th century (Capps et al., 2005; Wortham, Murillo, \& Hamann, 2002). The experience of ELL inclusion in traditionally monolingual English-medium classrooms has necessitated changes in many teachers' instructional practice, creating dilemmas for teachers unprepared through their professional training to work with such students (Arkoudis \& Davison, 2002; Reeves, 2004; Tellez \& Waxman, 2006).

As teachers seek solutions to the instructional dilemmas of ELL inclusion, there is a concurrent call for all teachers to see themselves as language teachers when ELLs are enrolled in their classrooms (Waxman, Tellez, \& Walberg, 2006). Overtures by, among others, the U.S. Department of Education's Office of English Language Acquisition (OELA), promotes the view that all teachers of ELLs are teachers of language, even if teachers' primary mission is teaching history, mathematics, science, or another content area. If content teachers were to widen their teacher identity to include that of language teacher, proponents argue that ELLs would benefit from teachers' increased attention to language in the content area (Echevarria, Vogt, \& Short, 2004; Waxman et al., 2006). However, calls for teachers to adopt a language teacher identity in their content area classrooms, regardless of the sound theoretical base from which it comes, may not translate smoothly into teacher action. Teachers, for example, may not know how to enact that role, or they may be resistant to adopting it for a wide variety of reasons 
(Reeves, 2004). Shifting teachers' view of their instructional responsibilities from that of subject area knowledge to subject area knowledge plus language requires educators to not only adopt new instructional strategies but also to renegotiate their teacher identity. The dilemma of ELL inclusion is not only instructional; it is also one of teacher identity.

The newly multilingual classroom, in which ELLs enroll in traditionally monolingual spaces, provides a fruitful arena for the study of teacher identity negotiation because the inclusion of students with limited English commonly interrupts the everyday flow of a classroom in which all parties previously shared a common language. Such interruptions arise not only from the commonly observed communication barrier between English-speaking teachers and limited English-speaking students (Harklau, 1999, 2000; Olsen, 1997; Reeves, 2004; Valdes, 2001), but also from the identity work of both teacher and student. Yoon (2008) observed teachers experiencing dilemmas of identity in response to the inclusion of ELLs in three middle school English language arts classrooms. Yoon's participant teachers positioned and repositioned themselves as either "teachers for all students, as teachers for regular education students, or as teachers for a single subject" (p. 515). As teachers repositioned themselves, they also changed their pedagogi$\mathrm{cal}$ approaches to correspond to the new identity position. For example, Mrs. Young, one of Yoon's participants, asserted her role as a teacher of all students. "I am a teacher of children.I am supportive of their [ELLs] learning" (p. 505). As a result of this identity position, Mrs. Young's pedagogical approach to teaching English language arts changed with the inclusion of ELLs to include discussion and validation of ELLs' cultural and linguistic experiences (e.g. inviting ELLs to share their home countries' Thanksgiving holidays and asking English-speaking students to put themselves in ELLs' linguistic shoes).

Although the study of teacher identity is a growing field (Johnson, 2006; Lasky, 2005; Marsh, 2002; Soreide, 2006; Watson, 2006), the ways teacher negotiate identity in relation to students, and in relation to ELLs in particular, has not yet been considered in any depth in educational research. The present study aims to address this research shortcoming by explicating the process by which one teacher (Neal) negotiated his identity through his assignment of identity positions to ELLs that complemented his own claimed identity, thereby investing in ELLs' identity.

While teacher identity in relation to ELLs has received little research attention, a promising and related body of research into the identity work of ELLs in K-12 schooling provides useful background and insight into the present inquiry (Fu, 1995; Goldstein, 2003; Harklau, 2000; Olsen, 1997; Toohey, 2000). Such inquiries typically include reference to ELLs' content area teachers as influential actors in ELLs' identity construction. These portrayals of content area teachers, which are not the main focus of these inquiries, are largely unflattering and unidimensional and present teachers who are mostly insensitive to the identities, experiences, and needs of ELLs (e.g. Fu, 1995; Harklau, 2000; Olsen, 1997). The accuracy of these portrayals is not questioned here. Rather, accepting the premise that teacher identity influences teacher interaction with students, the present inquiry takes up teacher identity as its main focus with the intention of adding nuance and depth to our understanding of teacher identity in relation to ELLs.

School-age ELLs in the United States are linguistic newcomers as well as cultural newcomers and/or outsiders who, as one might expect, experience identity challenges in negotiating life between and among multiple languages, cultures, and countries. This has not been lost on educational researchers who have produced a solid body of scholarship on the identity work of ELLs in multiple settings (Fu, 1995; Goldstein, 2003; Harklau, 2000; Olsen, 1997; Toohey, 2000; Yoon, 2008). Much of this research illuminates the complex interplay between self, other, and context in ELLs' identity work. This research sheds some light on the role content area teachers may play in ELLs' identity negotiations. Harklau (2000), for example, uncovers teachers' (and institutions') powerful positioning of ELLs as 'good kids' and the 'worst.' In this case, the good and the worst were one and the same ELLs, and the teachers' positioning was alternately accepted by the ELLs (when positioned as good kids) and resisted (when positioned as the worst). In both positive and negative ways, ELLs were subject to powerful identity positioning by their teachers and schools, and these assigned identity positions opened and limited ELLs identity options as well as their access to educational opportunity and advancement. Previous inquiry into ELLs' identity work, therefore, offers avenues for understanding the complex factors at play in identity negotiation not only for ELLs but also for others, including their teachers. Because teachers were not the focus of Harklau's and others' studies (e.g. Fu, 1995; Olsen, 1997; Valdes, 2001), these inquiries, understandably, leave teachers' own identity work unexamined or treated only superficially. By shifting the focus to teachers, a fuller explanation of the relationship between ELLs and their content area teachers can be drawn.

\section{Theoretical Framework}

The examination of teachers' identity work undertaken here is situated within scholarship that views identity as a "relational and sociocultural phenomenon that emerges and circulates in local discourse contexts of interaction rather than as a stable structure located primarily in the individual psyche or in fixed social categories" (Bucholtz \& Hall, 2005 , pp. 585-586). Recently identity theories have attended to the social negotiation of identity as well as the power of individual agency (Bucholtz \& Hall, 2005; Canagarajah, 2004; Lasky, 2005; Marsh, 2002; Morgan, 2004; Pavlenko \& Blackledge, 2004; Varghese, Morgan, Johnston, \& Johnson, 2005). This conceptualization of identity as socially negotiated, dynamic, and fragmented stands in contrast to the historical view of identity as internal, fixed, and coherent.

The social negotiation of identity, in which others (e.g. other people as well as external discourses) exerts influence in identity construction, coexists with individuals' agency. Individuals, while subject to external influences on their identity, can construct, adopt, and reject identity positions for themselves. The defining power previously granted external forces in a Marxist construction of identity has been moderated with a recognition of the power of the self to exert identity positions (Morgan, 2004). In this mediated view, identity construction is a negotiation with self, with others, and within the discourses present in one's life. Complicating matters, these forces wield uneven power and influence in identity construction and negotiation. Therefore, while "identity can never be something that is just interior because identity is necessarily relational," (Watson, 2006, p. 509), neither is the self-entirely "passive vis-à-vis the reproduction of dominant class interests" (Morgan, 2004, p. 173).

As people negotiate identities, they take up, assert, and resist identity positions that define them. This negotiation of identity happens continually in sustained relationships as well as in brief encounters. "[E] ven in the most fleeting of interactional moves, speakers position themselves and others as particular kinds of people" (Bucholtz \& Hall, 2005, p. 595). As a predictable outcome of an identity that is discursively constructed, the positions people take up for themselves are intertwined with the positions they ascribe to others (Bucholtz \& Hall, 2005; Harré \& Moghaddam, 2003; Johnson, 2006; Wilkinson \& Kitzinger, 2003). These dialectic relationships between self and other(s), between internal and external, lay at the heart of identity work.

Within a sociocultural frame of identity construction, the present study takes on the task of explicating the relationship between the teacher-self and the student-other. Such a task draws explanatory power 
from positioning theory (Harré \& van Langenhov, 1991, 1999) and Bucholtz and Hall's (2005) principle of positionality, one of five principles within their sociolinguistic model of identity. ${ }^{1}$ Positioning and positionality refer to the manner in which temporary roles (identity positions) are strategically claimed (and abandoned) by the self as well as the ways in which a person (or discourse) assigns identity positions to others. An identity position is "a loose set of rights and duties that limit the possibilities of action" (Harré \& Moghaddam, 2003, p. 5). The parameters of identity positions (whether the position is claimed or assigned) define what is expected of and socially possible for an actor.

Assigning an identity position to one's self or to an other is positioning.

Positioning can be understood as the discursive construction of personal stories that make a person's actions intelligible and relatively determinate as social acts and within which the members of the conversation have specific location (Harré \&van Langenhove, 1999, p. 395).

As an example, adopting the identity position of a maternal teacher opens particular avenues of socially expected behavior for a teacher (e.g. encouraging students with kind words) while closing others (e.g. using public humiliation as a discipline technique). Harré and Moghaddam (2003) observed that "[p]ositioning someone, even if it is oneself, affects the repertoire of acts one has access to" (p. 5). As the above example illustrates, the identity positions teachers claim for themselves and assign to others hold important implications not only for teachers' practice (what they can and ought to do in the classroom) but also their students' access to particular identities (e.g. the identity of a capable learner).

To further explicate the positionality of identity construction, we can turn to the methods actors use in positioning self and others. In constructing identities, people tell stories or ontological narratives, "in an effort to make sense of how we experience ourselves and how we would like to be understood in order to bring structure to our personal lives" (Soreide, 2006, p. 529). These self-narratives utilize reflective and interactive positioning as identity construction tools (Harré \& van Langenhove, 1999; Harré \& Moghaddam, 2003; Yoon, 2008). Reflective positioning refers to a person's assertion of an identity position for the self (selfpositioning). Interactive positioning is ascribing an identity position to an other (other-positioning), and this kind of positioning is akin to the principle of indexical inversion described by Bucholtz and Hall (2005). An index is a linguistic form loaded with social meaning and invoked to assert particular, strategic identity positions. In indexical inversion, the indexical associations are "imposed from the top by cultural authorities such as intellectuals or the media," (p. 596) or, in the teacher-student relationship, indexes are imposed from the most to least powerful (i.e. from teacher to student). Teachers may index ELLs as particular types of learners, and teachers typically have considerably greater power to enact that other-positioning in the school setting than do students, as Harklau's (2000) and Yoon's (2008) research indicates.

Other-positioning is often, as Harre and Moghadamm explain, "thrust.upon someone without explicit intentions" (Harré \& Moghaddam, 2003, p. 7). Because identity is relational, simply asserting one's own identity position may have unintended identity implications for others in relation to that person; and many examples of other-positioning are not deliberate or Machiavellian in nature. Yoon's participant, Mr. Brown, claimed the identity position of a teacher of "regular" education students, not a teacher of ELLs, even though his language arts course enrolled ELLs.

As a teacher of regular students, Mr. Brown made no accommodations (linguistic, cultural, or otherwise) for ELLs, and his instruction made frequent use of American popular cultural references, which were lost on the ELL newcomers. By acting through his claimed identity position, Mr. Brown "unintentionally positioned the ELLs [in his classroom] as isolated and powerless" (p. 517). In this way Mr. Brown's reflective positioning of self had unintended negative consequences for ELLs.

Yet, it may also be the case that the positioning of an other is deliberate and an intentional maneuver as an actor constructs his own identity construction. Deliberate interactive positioning assigns identities to others that are complementary to the self. Such other identity assignments draw comparisons between the self and other, highlighting, for example, similarities and/or differences.

Deliberate other-positioning highlights the vested nature an actor may have in another's identity positions. What is intimated but as yet unexplored in positionality and positioning theory is the investment an actor may make in an other's identity. The concept of investment when applied to identity construction may offer insight into not only how deliberate self and other-positioning work but also why an actor deliberate positions self and other in particular ways. Norton Peirce (1995) used the term investment in her work on second language learners' motivation to describe learners' commitment to second language learning and their vested interest in particular social identities.

[I]f learners invest in a second language, they do so with the understanding that they will acquire a wider range of symbolic and material resources, which will in turn increase the value of their cultural capital. Learners will expect or hope to have a good return on that investmentda return that will give them access to hitherto unattainable resources (p. 17).

This use of the term finds its roots in Bourdieu's notion of cultural capital, in which particular knowledge is given greater or lesser exchange value in given social contexts.

Borrowed from Norton Pierce, the term investment is employed here to highlight that the indexical relationship between self and other may be similar to that of economic exchange. An actor invests in the identity of an other (by positioning the other) in order to achieve a return, that is, in order to assert and reinforce a self-identity. By extending positioning theory to include the notion of identity investment, it can be hypothesized that actors may intentionally position others as a means to further the actor's own identity positions, that actors hold and act on a vested interest in others' identities positions. The present inquiry pursues this hypothesis in a school setting in which an actor (a teacher) invests in the identity of a group of learners (ELLs) as a means to support his own self-positioning.

The teacher-ELL relationship is one of a number of relationships in which teachers negotiate identity. Teacher identity studies, therefore, could also articulate teachers' positioning of self in relation to non-ELL others or contexts such as work-site narratives, community discourses, school reform efforts (Lasky, 2005)or educational policies (Varghese $\&$ Stritikus, 2005). Here, for purposes of space and to foreground the topic that is underdeveloped in the literature (i.e. how teachers negotiate their identities in relation to ELLs), the teacher positionings of self and ELL are examined and discussed, yet this does not mean that other identity forces were not at play beyond the teacher-ELL relation. Further, the positionings presented here are from the perspective of the teacher, therefore, the identity positions are self-narrations of who the teacher is in relation to teacher-positioned others (i.e. ELLs). ELLs' ontological narratives are not highlighted, but were they, the identity stories would likely be markedly different.

Finally, it is important to note that ELLs are a heterogeneous group of learners, and the positioning of ELLs, who evidence a great diversity 
in language, education, and cultural backgrounds, as a monolithic type of learner is fraught. Nonetheless, making generalizations about groups of learners in order to provide appropriate instruction is what teachers are expected to do. After all, U.S. federal law requires identification of ELLs and modification of the instruction they are to receive. This inquiry, while it does not pursue full explication of the dilemma of generalization or ultimately suggests solutions, does inform our understanding of teachers' practice of generalization.

\section{The Study}

Data come from a larger one-year mixed method study of secondary content area teachers of ELLs. The purpose of the original study was to investigate teachers' attitudes and perceptions of ELL inclusion. Quantitative data on teachers' attitudes and perceptions were gathered through a large-scale survey of 279 high school teachers in a large southeastern U.S. school district that was just beginning to see substantive growth in its ELL enrollment. Qualitative data in the form of case studies were collected on teachers' experiences with ELL inclusion in four secondary content area classrooms. The teacher (identified through the pseudonym Neal) discussed in this report was among the four participants in the qualitative inquiry. Neal's case was particularly compelling among the four qualitative participants because, as the data illustrate, he actively and aggressively claimed identity positions for himself and assigned positions to others. Neal was a first-year teacher at his school site (although he had three years of previous experience elsewhere), and his active identity construction has stemmed from his role as the new teacher.

Neal was a young teacher in his mid-20s who had worked with few ELLs in his English language arts classes. He had taught approximately 12 ELLs in his four years of teaching, and during the course of the study Neal taught four ELLs across two classes. Neal, like the great majority of his teaching colleagues at Eaglepoint High School (a pseudonym), was white (approximately $80 \%$ of Eaglepoint faculty) and a native speaker of English ( $99 \%$ of faculty). Neal had some beginning conversational ability in Spanish, but he never used Spanish with his Spanish-speaking students as a point of principle. Neal had not participated in any pre-service or in-service training for working with ELLs.

Neal's school site was one of 12 high schools in a large countywide school district. During the year of the study, 32 students (1.6\%) at the high school were identified as non-English language background (NELB).

Data collection occurred over the course of the 2001-2002 academic year when the district was in the process of instituting high-stakes tests including standardized end-of-course exams for all core content areas. Collection procedures consisted of audio-taping a series of long interviews with participant teachers, writing notes from informal conversations (meetings in the halls, conversations before and after class), observing and scripting 90 min lessons on a weekly or biweekly basis, and gathering course documents such as homework assignments, quizzes, and tests. The high school in which Neal taught utilized block scheduling, and traditional year-long courses were instead taught intensively over the course of one semester in 90-min periods per day.

Language, in a sociocultural view of identity, is the primary medium for identity construction, so interviews, conversations, and observations were considered arenas of participants' identity negotiation and the field notes and transcripts of these events became artifacts of Neal's identity narrative (Bucholtz \& Hall, 2005; Johnson, 2006; Morgan, 2004; Varghese et al., 2005).

With the aid of NU*DIST qualitative research software, data were analyzed iteratively, and analysis began with data collection. The software also aided in the identification of patterns within and among par- ticipants' data through keyword searches and the program's coding mechanisms. Data patterns within and across data sources were sought in teachers' identification and labeling of self and ELLs, and particular attention was given to the language (e.g. vocabulary, metaphors, analogies) participants used to describe themselves and the ELLs they taught. Within the data collected on Neal, for example, a pattern of identifying himself in opposition to other teacher was identified, and supporting data were labeled "oppositional teacher identity." After salient patterns were identified by searching all data sources for verifying and contradictory evidence, an initial report was produced and member checked with Neal whose feedback provided clarification and additional data.

\section{The Original Slim Shady}

Throughout the study, Neal claimed numerous identity positions. The three most strongly claimed and commonly occurring were (1) Neal as a stern, tough-love teacher; (2) Neal as a hip, irreverent teacher in touch with his students; and (3) Neal as a natural and highly competent teacher.

Time and again throughout the study in interviews with the researcher, Neal asserted an identity position of a stern, tough-love teacher, describing himself as "stern," "abrasive," and "not maternal" (Neal, interview, November 2, 2001). Observation data from his classroom indicated that he acted on this self-position. He brooked little dissent from students. "I want my kids to be scared when they don't know the answer" (Neal, interview, November 2, 2001, p. 3). During an observation when students continued to get out of their seats despite his repeated warnings to remain seated until the bell rang, he responded pointedly and sarcastically, "Let me repeat something I just said, SIT DOWN" (Neal, observation, October 25, 2001). Hearing Neal's tone, the students scurried to their seats. Neal was no more indulgent of ELLs poor performance and misbehavior. He viewed ELLs as needing a firm hand as much as non-ELL students. "No, I don't cut anybody a breakever.it's [the situation with ELLs] just like any native English-speaking kid. They know the rules [of grammar], whether or not they apply them is another matter" (Neal, interview, October 24, 2001, p. 5). Despite his brusque response to misbehavior and his desire to be viewed as a stern teacher, Neal was also concerned that his students knew that he cared for them and that his tough-love approach to teaching was meant to prepare them for life in the real world.

The second identity position Neal asserted during the course of the study was that of a hip, irreverent teacher who was in touch with youth culture, telling his students, "I was the original Slim Shady ${ }^{2}$ " (Neal, observation, December 6, 2001). Neal's fast-paced lessons were peppered with such pop-cultural reference. He felt his relationship with students was stronger than most teachers not only because of his age proximity with students (Neal was in his mid-20s) and his knowledge of youth culture, but also because he was more naturally attuned to students and had an easy rapport with them.

I have a pretty good rapport with my students. In a way that I don't think many other teachers have. I mean I haven't sat in on a lot, you've [researcher] seen more than I have. But I think that as far as the rapport that I have with students, I've been told by observers before and by the kids that, you know, I say things more clearly that they understand. They understand me better. I mean that's probably one of my biggest gifts as a teacher. I'm pretty good at, with any kid to be able to read when they don't understand. And so, and that, I think I pay more attention to it (Neal, interview, December 6, 2001, pp. 4-5). 
The third identity position that Neal asserted was that of a natural teacher, one who might have not had impeccable lesson plans, but one who connected with students and was, therefore, an extraordinarily good and effective teacher.

I think that, you know, you [researcher] said that there are not natural teachers, and everybody has to work at it. I don't believe that, because I've walked into classrooms and I've thought, how can this person be a teacher? And they have impeccable lesson plans. And you know, they might know the subject matter better than me, but they cannot teach. So, I think that in my case, anyway, and I may really, the day I walked in the classroom I knew that this is it. I love being in front of the class, and I love teaching (Neal, interview, November 2, 2001, p. 4).

The identity position of the natural teacher was complemented by $\mathrm{Ne}$ al's other two self-positioned identities, that of a hip, irreverent teacher and a stern, tough-love teacher.

As Neal's self-positionings suggested, much of his identity narration was "positioning through opposition" (Soreide, 2006, p. 534) in which he took up subject positions that placed him in contrast with the identity positions he ascribed to other teachers. Unlike himself, for example, Neal observed that most of his peers were not naturals at teaching. Additional other-positioning emblematic of this stance included, "I don't think that what I do would work for many other teachers" (Neal, interview, November 2, 2001, p. 5), and "I have pretty good rapport with my students in a way that I don't think many other teachers have" (Neal, interview, December 6, 2001, p. 4). By being a natural, Neal also positioned himself as an unusually effective teacher, again, in contrast to his colleagues.

You can ask any kid in my class, 'Have you learned more in here than you have in any other English class,' and I know that sounds pompous, but they will honestly tell you, 'Yes, I have.' At least 80 percent of them (interview, November 2, 2001, pp. 4-5).

Neal's other-positioning of his teaching colleagues as overly maternal, out of touch with students, and not natural teachers served to strengthen his own oppositional self-positionings. He claimed the identity positions his colleagues could not.

Neal also highlighted the difference between himself and his colleagues in the oppositional ways each positioned ELLs. Neal perceived his colleagues to position ELLs as different from other students and in need of special care, which, in Neal's view, only served to disadvantage ELLs.

\begin{abstract}
Neal: It's easier for teachers just to give the kid the answer than explain to them. And I think that that's the way the kids get cheated. Okay, here, fine, here's the answer. I mean, I don't shorten assignments for kids. Because if they're really going to be part of this society, and they're really going to function in it, then they're going to overwhelmed for a while, and I don't shorten assignments. I give them more time to do them, but I will never shorten an assignment for an ESL [English as a second language] student.

Researcher: Yeah. But you've seen other teachers do that? Neal: I haven't seen it as much as I can tell from the way the kids behave that it happens (interview, December 6, 2001, p. 6).
\end{abstract}

In opposition to his colleagues' positioning of ELLs, Neal's primary positioning of ELLs was "just like any [other] kid" (Neal, interview, October 24, 2001, p. 5), and he argued for the need to treat ELLs like any other kid. "I know how to teach English and that's what they're [ELLs] trying to learn" (Neal, interview, October 24, 2001, p. 3). In this positioning of ELLs, kids were kids regardless of language proficiency or background. The learning of English was no different, or at least not signif- icantly different, for ELLs than it was for English proficient students. While Neal did note that ELLs had a linguistic difference in that they were not yet proficient in English, this difference held little saliency for him. The elimination of the linguistic difference, in Neal's view, was important for life beyond schools, and the way to eliminate ELLs' linguistic difference was to ignore it. "[I]n society it's not like you're going to wear a badge that says 'English is not my first language. Be Patient.' You know? Everybody can't.and so, I mean, and that's how I always try to apply it, to society" (Neal, interview, October 24, 2001, p. 7).

Because he positioned them as the same as all other students, Neal did not alter instruction for ELLs. The identity position he assigned ELLs was strategically complementary to the subject position he frequently adopted for himself as a natural and highly competent teacher (of ELLs and non-ELLs alike).

The only modification that I made for an ESL student is extend the time. Other than that I tend to think it's unfair. I mean, I don't, I hate giving extra time to students. I have one student who supposedly can't read, so I had his tests given to him orally, and I can't stand that because he, like I know that there's some way in presenting it that they're helping him with it. I don't know what it is because I've never sat in on it, but I know he doesn't know some of the words he comes back with correct answers to, you know, that kind of thing. So, I tend to think that as little as possible is better. Not to mention, you know, five years from now, nobody's going to say, [mocking] 'Would you like more time on this job because you don't speak English?' You know, nobody does that.if it's unfair to anybody, it's unfair to them (Neal, interview, November 2, 2001, p. 8).

Neal asserted that it was his role as a good and effective teacher to prepare ELL and all students for 'society,' and that meant viewing and treating ELLs like all other students.

\subsection{Teacher investment in ELL Identity}

Neal's case, while it cannot and is not intended to speak for all content teachers' experiences with ELL inclusion, reveals how positioning and investment play out through one teacher's identity work. As Neal negotiated his teacher identity, he did so in relation to others and through the deliberate positioning of himself, other teachers, and ELLs. As the data reveal, Neal's school and classroom were sites rich with identity negotiation.

Not only were Neal's school and classroom sites for his identity negotiation, they were sites that allowed for, even encouraged, deliberate (rather than simply unintentional) self-and other positionings. Neal exhibited deliberate positioning of himself, his colleagues, or ELLs, in which he actively claimed and assigned identity positions. Perceiving that he might be positioned like other teachers in his school setting (e.g. maternal, out of touch, less than entirely competent), Neal strongly asserted an oppositional identity. In this way, Neal utilized what Harré and van Langenhove (1999) term second order positioning. "[S]econd order positioning occurs when the first order positioning is not taken for granted by one of the persons involved" (Harré \& van Langenhove, 1999 , p. 396). In Neal's case he perceived first order positioning of himself as like other teachers at Eaglepoint. Neal was a newcomer to this school site (his first year at Eaglepoint), and he was deeply involved in identity negotiation. The predominant identity positions that Neal claimed were in rejection of the institutional identity of teachers Neal perceived. He negotiated his desired identity positions not only through deliberate self-positioning statements but also through the deliberate positioning of two others: his teaching colleagues and ELLs.

Neal defined himself as related to other teachers in an oppositional way, and as part of his other-positioning of his colleagues, Neal assigned 
an other position to ELLs as just like any other student. It was in the manner in which he negotiated his identity in relation to ELLs that Neal's investment in learner identity is revealed. Neal's claimed identity was enabled, in part, through the identity he assigned ELLs, and he invested in ELLs' identity in order to further his own preferred identity positions. Positionality was not only relational in Neal's case, it was also imbued with Neal's self-interest and investment in others' identities.

Had Neal assigned ELLs an identity position of different from other students, he might then have been required to admit being out of touch with ELLs and not being entirely competent to teach them. Such an admission would have been in conflict with the teacher identity he chose to claim so stridently. As Neal invested in his claimed identity, he simultaneously and necessarily invested in assigning ELLs an identity that was complementary. By investing in such an identity for ELLs, Neal strengthened his identity position as the highly competent, young teacher who was more than capable of reaching all students. In this way his investment in ELLs' identity bore a return in the form of a strengthened self-identity.

Neal's investment in ELLs' identity was similar to Norton Peirce's (1995) conceptualization of learners' investment in second language learning in that the term indicates an economic transaction. In this case Neal seeds the identity of his learners in ways that will complement and enhance his own claimed identity; he makes an investment in others' identity in order to see a return. That return was a strengthening of his own claimed identity. His interest in ELLs' identities was, therefore, vested.

Interestingly, at one point Neal did shift his identity position in regard to ELLs, fleetingly positioning them as unlike other students and positioning himself as unable to meet their needs: "I wish that there was more that I could do to help them [ELLs]. I mean we don't have the training to help the kids in the way that we need to" (Neal, interview, December 6, 2001, p. 6). In this conversation Neal was discussing the importance of establishing a relationship with all of his students. The above quote came at the end of our fourth and final long interview and in response to the question "Do you have any other comments in general on the experience of having ESL students in your classes?" His response, then, was salutatory in nature, his closing remarks on what had been, up to that point, a semester-long collaboration with the researcher. Interestingly, when Neal adopted this stance he also abandoned his typically oppositional approach to identity construction by aligning himself with other teachers, signaled by his use of the pronoun we. In this way Neal positioned himself as inadequate, but not solely inadequate, implicating other teachers as well. Aligning himself with other teachers was a significant identity shift for Neal. This finding, that Neal's claimed identity shifted, is in line with the sociocultural view of identity as in flux and changeable (Bucholtz \& Hall, 2005; Canagarajah, 2004; Morgan, 2004; Varghese et al., 2005), and the circumstances that accompany such shifts in teacher identity positions may prove fruitful ground for further research. Nonetheless, data overwhelmingly revealed Neal's strong investment in ELLs identity as like any other student.

\section{Discussion}

Positioning ELLs (and other students) as particular types of learners provides teachers with a necessary mechanism for reasoning through the complex task of teaching and making sense of how to instruct large numbers of students with varied needs and backgrounds within a classroom. What are potentially problematic in teachers' positionings of ELLs and other learners are the attitudes, beliefs, and discourses that teachers utilize in ascribing identity positions to learners. Teachers' understanding of second language acquisition processes, their attitudes toward immigrant and newcomer students, their buy-in or resistance to community and school discourses about ELLs, among innumerable other variables, inform identity positioning. To the extent that teachers hold misconceptions regarding second language learning, assimilative impulses toward ELLs, or biases against immigrant students or particular immigrant groups, the likelihood of teachers positioning ELLs in unhelpful or even damaging ways increases. The findings of this study also indicate that teachers may invest in particular identity positions for ELLs as a means to negotiate teachers' own identities, exposing teachers' self-interest in defining who learners are.

Teacher identity construction in relation to learners, and the concomitant investment teachers make in learners' identities, is, as Neal's case demonstrates, potentially problematic for two reasons: (1) the subsequent denial of the saliency of linguistic difference in ELLs' educational access and academic achievement and (2) the limited power ELLs have to resist their teacher-assigned identity positions. First, in positioning ELLs as like any other student, ELLs' linguistic (as well as cultural and other) differences are denied saliency (Kubota, 2004). Neal's investment in ELLs' identity position as like any other student resulted in his refusal to make linguistic accommodation for ELLs during instruction. Such undifferentiated instruction could actually be instructing for one student, the prototypical student who is a white, middle class, English monolingual (McLaren, 1997), and failing to take ELLs' linguistic assets and limitations into account may be setting students up for failure as ELLs' access to content is restricted by their comprehension of instruction that takes place in a language in which they are not proficient. In turn, ELLs might then be blamed for failing to achieve when given an equal chance, as the following quote from Neal intimates.

I know how to teach English and that's what they're [ELLs] trying to learn.they're doing what they need to be doing. They're speaking, they're writing, or reading and a lot of times I think that the problem is whether or not the child decides if they want to or whether or not that they think that they can. They say they can't, well then they won't (Neal, interview, October 24, 2001, p. 3).

Neal's stance on ELLs and undifferentiated instruction are indicative of an assimilative approach in the education of ELLs. In a previous report on Neal and other content area teachers at Eaglepoint, teachers were observed to recognize that ELLs were not like everybody else, yet the teachers treated ELLs like any other student (Reeves, 2004). The teachers did so because they considered equal treatment effective in promoting ELLs' rapid acquisition of English and subsequent assimilation into the school and wider communities. Differences were recognized but that teachers attempted to assist ELLs with assimilation by erasing those differences. In essence, this positioning of ELLs asserted the teacher's view that ELLs will (and ought to) be like any other student if treated as such.

While positioning ELLs as like every other student is problematic, so, too, could be the positioning of them as dramatically different from other students. If, in constrast to Neal's case, teachers positioned ELLs as unlike any other student, this could, again, reveal a teachers' image of the prototypical student as a white, native English-speaking monolingual (Kubota, 2004; McLaren, 1997) and the realization (and possible teacher frustration) that ELLs do not fit that image. The view of ELLs as dramatically different from non-ELL students could widen the achievement gap between non-ELLs and ELLs as teachers lowered expectations for ELLs who are not only viewed as different but also deficient. Positioning ELLs as dramatically different from other students could overplay ELLs' differences and encourage teachers to lower academic expectations for ELLs.

Teachers' investment in ELLs' identity is also concerning because teachers have greater power than students in educational settings to enact teacher-assigned identity positions, and ELLs, as non-proficient 
English speakers in an English-medium setting, have even further reduced power to reposition themselves in English. Marsh (2002) highlighted the consequential nature that self-positioning has on related others.

As individuals piece together identities from the discourses that are made available to them, they simultaneously create possibilities and constraints for the identities of those with whom they are in relationship. Conceptualizing the construction of the self as relational means that choosing to author one's self-identities in particular ways directly impact the social identities that can be formed by others (pp. 334-335).

Although learners have agency and may refute or resist an assigned identity (Canagarajah, 2004; Harklau, 2000), ELLs in English-medium school settings have limited power to do so (Cummins, 2001; Harklau, 2000; Morgan, 2004; Pennycook, 2001). As Cummins (2001) observed, the micro-interactions within the teacher-student relationship are never neutral; these interactions employ coercive or collaborative power. Teachers, although themselves also constrained at times by coercive power relations within their school and home community,

do have choices in the way they structure the interactions in the classroom. They have some degree of freedom in determining the social and educational goals they want to achieve with their students. They are responsible for the role definitions they adopt in relation to culturally diverse students and communities (p. 21).

Further, as proficient (and very often native) English speakers, teachers have the linguistic resources to enact identity positions that ELLs, as limited English speakers, do not.

By analyzing teacher identity negotiation through positioning theory and the concept of investment, the finding of this study indicates that teachers may investment in ELLs' identity strategically in order to advance their own self-positionings. Such positionings are potentially problematic for ELLs, which raises the question of what teacher preparation and development can and ought to do.

First, in light of the import of teacher identity construction in teachers' lives, their practice, and their students, teacher education ought to be responsive to how identity may affect teacher learning and change. The power of teachers' identities work to shape teacher action, as in $\mathrm{Ne}$ al's case, deepens skepticism that skills-based teacher preparation is sufficient to prepare educators for today's classroom. Neal, for example, was a teacher who was likely to be resistant to receiving training in the use of accommodative instructional strategies for ELLs because he invested in ELLs' identity as like any other student who would not need accommodation. The quandary for teacher training and professional development, then, becomes how to facilitate teacher identity construction that builds teacher competence and expertise. Two avenues present themselves for disrupting teacher (and others') investment in problematic identity positions for ELLs: heightened teacher awareness of identity issues and deliberate institutional positioning and investment in positive learner identities.

Heightening teacher awareness of identity construction (teachers' own and their students') may compel teachers to reexamine their own identity construction and its consequences. Teacher education ought to help teachers see the underlying power relations that shape and limit identity construction as well as the, sometimes unintended, consequences of identity negotiation on teachers' practice. By inviting teachers to interrogate the forces, both internal and external, that shape their identity options, identity construction is made explicit and can itself become an object of study. Several approaches to teacher education hold promise in this endeavor, including the use of teacher autobiography (Johnson, 1999; Morgan, 2004), teacher and learner case studies (Grossman, 2005), and teacher self-study (Macintyre Latta et al., 2007). Considering the potential consequences for teachers' identity construction and for student in whose identities teachers invest, there is a pressing need for educational researchers and teacher educators to better understand the nature of teacher identity construction.

Secondly, school narratives of who ELLs are should deliberately, rather than unintentionally, steer institutional representations of ELLs. Neal's school was largely silent on who ELLs were and how they ought to be educated, which allowed each teacher the opportunity to position ELLs as they preferred. Certainly coercive tactics by school administration to force teachers to adopt an identity view of ELLs is not advocated here. However, setting a school-wide policy toward ELL education which positions ELLs as capable, legitimate learners could establish a school-wide positioning of ELLs, setting a positive tone and discouraging negative (if unintended) ELL positioning. Further, working to open a wider space for ELLs' own self-positioning ought to be a part of such a school-wide initiative.

In conclusion, teachers' investment in learners' identity requires more investigation. The findings from this study raise new questions about identity work in schools, namely (1) how might identity investment be used as a positive force in teacher-student relationships; (2) how can educational researchers interrogate and illustrate the complex web of identity positionings within schools and classrooms; and (3) what avenues and options do students (and teachers) have to resist unwanted identity positionings and investments? This study explicated the process by which one teacher invested in the identity of ELLs, laying the groundwork for further exploration.

\section{References}

Arkoudis, S., \& Davison, C. (2002). Breaking out of the billabong: mainstreaming in Australian schools. In: E. P. Cochran (editor), Mainstreaming (pp. 53-67). Alexandria, VA: Teachers of English to Speakers of Other Languages.

Bucholtz, M., \& Hall, K. (2005). Identity and interaction: a sociocultural linguistic approach. Discourse Studies, 74, 585-614.

Canagarajah, S. (2004). Subversive identities, pedagogical safe houses, and critical learning. In: B. Norton, \& K. Toohey (editors), Critical Pedagogies and Language Learning (pp. 116-137). Cambridge, U.K.: Cambridge.

Capps, R., Fix, M., Murray, J., Ost, J., Passel, J. S., \& Herwantoro, S. (2005). The New Demography of America's Schools: Immigration and the No Child Left Behind Act. Washington, D.C.: The Urban Institute.

Cummins, J. (2001). Negotiating Identities: Education for Empowerment in a Diverse Society (2nd edition). Los Angeles: CABE.

Echevarria, J., Vogt, M., \& Short, D. J. (2004). Making Content Comprehensible for English Learners: The SIOP Model (2nd edition). Boston: Pearson.

Fu, D. (1995). My Trouble is My English: Asian Students and the American Dream. Portsmouth, N.H.: Heinemann.

Goldstein, T. (2003). Teaching and Learning in a Multilingual School: Choices, Risks, and Dilemmas. Mahwah, N.J.: Lawrence Erlbaum.

Grossman, P. (2005). Research on pedagogical approaches in teacher education. In:M. Cochran-Smith, \& K. M. Zeichner (editors), Studying Teacher Education: The Report of the AERA Panel on Research and Teacher Education (pp. 425-476). 
Harklau, L. (1999). The ESL learning environment in secondary school. In: C. J. Faltis, \& P. M. Wolfe (editors), So Much to Say: Adolescents, Bilingualism, and ESL in the Secondary School (pp. 42-60). New York: Teachers College Press.

Harklau, L. (2000). From the 'good kids' to the 'worst': representations of English language learners across educational settings. TESOL Quarterly, 34, 35-67.

Harré R., \& van Langenhove, L. (1991). Varieties of positioning. Journal for the Theory of Social Behaviour, 21, 393-407. Harré R., \& van Langenhove, L. (1999). Varieties of positioning. Journal for the Theory of Social Behavior, 21, 393-407.

Harré R., \& Moghaddam, F. (2003). Introduction: the self and others in traditional psychology and in positioning theory. In: R. Harré \& F. Moghaddam (editors), The Self and Others: Positioning Individuals and Groups in Personal, Political and Cultural Contexts (pp. 1-11). Westport, CT: Praeger.

Johnson, G. C. (2006). The discursive construction of teacher identities in a research interview. In A. de Fina, D. Schriffin, \& M. Bamberg (editors), Discourse and Identity (pp. 213-232). New York: Cambridge.

Johnson, K. E. (1999). Understanding Language Teaching. Toronto: Heinle \& Heinle.

Kubota, R. (2004). Critical multiculturalism and second language education. In: B. Norton, \& K. Toohey (editors), Critical Pedagogies and Language Learning. New York: Cambridge.

Lasky, S. (2005). A sociocultural approach to understanding teacher identity, agency and professional vulnerability in a context of secondary school reform. Teaching and Teacher Education, 21, 899-916.

Macintyre Latta, M., Buck, G., Abrahams, T., Diaz DeBose, C., Dop, S., Fuchser, K., et al. (2007). Professional development risks \& opportunities embodied within self-study. Studying Teacher Education, 13(2), 189-205.

McLaren, P. (1997). Unthinking whiteness, rethinking democracy: or farewell to the blonde beast; toward a revolutionary multiculturalism. Educational Foundations, 11(2), 5-39.

Marsh, M. M. (2002). The shaping of Ms. Nicholi: the discursive fashioning of teacher identities. Qualitative Studies in Education, 15, 333-347.

Morgan, B. (2004). Teacher identity as pedagogy: towards a field-internal conceptualization in bilingual and second language education. Bilingual Education and Bilingualism, 7, 172-188.

Norton Peirce, B. (1995). Social identity, investment, and language learning. TESOL Quarterly, 29, 9-31.

Olsen, L. (1997). Made in America: Immigrant Students in Our Public Schools. New York: The New Press.
Pavlenko, A., \& Blackledge, A. (2004). Introduction: new theoretical approaches to the study of negotiation of identities in multilingual contexts. In: A. Pavlenko, \& A. Blackledge (editors), Negotiation of Identities in Multilingual Contexts. Clevedon, U.K.: Multilingual Matters.

Pennycook, A. (2001). Critical Applied Linguistics: A Critical Introduction. Mahwah, N.J.: Lawrence Erlbaum.

Reeves, J. (2004). 'Like everybody else': equalizing educational opportunity for English language learners. TESOL Quarterly, 38, 43-66.

Soreide, G. E. (2006). Narrative construction of teacher identity: positioning and negotiation. Teachers and Teaching: Theory and Practice, $12,527-547$.

Tellez, K., \& Waxman, H. C. (2006). Preparing quality educators for English language learners: an overview of the critical issues. In: K. Tellez, \& H. C. Waxman (editors), Preparing Quality Educators for English Language Learners: Research, Policies, and Practices (pp. 1-22). Mahwah, N.J.: Lawrence Erlbaum.

Toohey, K. (2000). Learning English at School: Identity, Social Relations and Classroom Practice. Clevedon, U.K.: Multilingual Matters.

Valdes, G. (2001). Learning and Not Learning English: Latino Students in American Schools. New York: Teachers College Press.

Varghese, M., Morgan, B., Johnston, B., \& Johnson, K. A. (2005). Theorizing language teacher identity: three perspectives and beyond. Journal of Language, Identity, and Education, 4, 21-44.

Varghese, M. M., \& Stritikus, T. (2005). "Nadie me dijo (nobody told me)": language policy negotiation and implications for teacher education. Journal of Teacher Education, 56, 73-87.

Watson, C. (2006). Narratives of practice and the construction of identity in teaching. Teachers and Teaching: Theory and Practice, 5, 509-526.

Waxman, H. C., Tellez, K., \& Walberg, H. J. (2006). Future directions for improving teacher quality for English language learners. In: K. Tellez, \& H. C. Waxman (editors), Preparing Quality Educators for English Language Learners: Research, Policies, and Practices (pp. 189195). Mahwah, N.J.: Lawrence Erlbaum.

Wilkinson, S., \& Kitzinger, C. (2003). Constructing identities: a feminist conversation analytic approach to position in action. In: R. Harre, \& F. Moghaddam (editors), The Self and Others (pp. 157180). Westport, CT: Praeger.

Wortham, S., Murillo, E. G., \& Hamann, E. T. (editors). (2002). Education in the New Latino Diaspora: Policy and the Politics of Identity. Westport, CT: Ablex Press.

Yoon, B. (2008). Uninvited guests: the influence of teachers' roles and pedagogies on the positioning of English language learners in the regular classroom. American Educational Research Journal, 45, 495-522. 